\title{
Enhanced production of oxidised mercury over the tropical Pacific Ocean: a key missing oxidation pathway
}

\author{
F. Wang ${ }^{1}$, A. Saiz-Lopez ${ }^{2}$, A. S. Mahajan ${ }^{2, *}$, J. C. Gómez Martín ${ }^{2, * *}$, D. Armstrong ${ }^{1}$, M. Lemes ${ }^{1}$, T. Hay ${ }^{2}$, and \\ C. Prados-Roman ${ }^{2}$ \\ ${ }^{1}$ Centre for Earth Observation Science, Department of Environment and Geography, and Department of Chemistry, University \\ of Manitoba, Winnipeg, MB R3T 2N2, Canada \\ ${ }^{2}$ Atmospheric Chemistry and Climate Group, Institute for Physical Chemistry Rocasolano, CSIC, Madrid, Spain \\ * currently at: Indian Institute of Tropical Meteorology (IITM), Pune, India \\ ** currently at: School of Chemistry, University of Leeds, LS2 9JT, Leeds, UK
}

Correspondence to: F. Wang (wangf@ms.umanitoba.ca) and A. Saiz-Lopez (asaiz@iqfr.csic.es)

Received: 6 August 2013 - Published in Atmos. Chem. Phys. Discuss.: 21 August 2013

Revised: 18 December 2013 - Accepted: 31 December 2013 - Published: 5 February 2014

\begin{abstract}
Mercury is a contaminant of global concern. It is transported in the atmosphere primarily as gaseous elemental mercury, but its reactivity and deposition to the surface environment, through which it enters the aquatic food chain, is greatly enhanced following oxidation. Measurements and modelling studies of oxidised mercury in the polar to subtropical marine boundary layer (MBL) have suggested that photolytically produced bromine atoms are the primary oxidant of mercury. We report year-round measurements of elemental and oxidised mercury, along with ozone, halogen oxides ( $\mathrm{IO}$ and $\mathrm{BrO})$ and nitrogen oxides $\left(\mathrm{NO}_{2}\right)$, in the $\mathrm{MBL}$ over the Galápagos Islands in the equatorial Pacific. Elemental mercury concentration remained low throughout the year, while higher than expected levels of oxidised mercury occurred around midday. Our results show that the production of oxidised mercury in the tropical MBL cannot be accounted for by bromine oxidation only, or by the inclusion of ozone and hydroxyl. As a two-step oxidation mechanism, where the $\mathrm{HgBr}$ intermediate is further oxidised to $\mathrm{Hg}(\mathrm{II})$, depends critically on the stability of $\mathrm{HgBr}$, an additional oxidant is needed to react with $\mathrm{HgBr}$ to explain more than $50 \%$ of the observed oxidised mercury. Based on best available thermodynamic data, we show that atomic iodine, $\mathrm{NO}_{2}$, or $\mathrm{HO}_{2}$ could all play the potential role of the missing oxidant, though their relative importance cannot be determined explicitly at this time due to the uncertainties associated with mercury oxidation kinetics. We conclude that the key pathway that significantly enhances atmospheric mercury oxida-
\end{abstract}

tion and deposition to the tropical oceans is missing from the current understanding of atmospheric mercury oxidation.

\section{Introduction}

Mercury is a contaminant of global concern due to its longrange transport via the atmosphere, bioaccumulation and biomagnification in aquatic ecosystems, and developmental neurotoxicity to humans (Selin, 2009). The biogeochemical cycle of mercury has been greatly perturbed by present-day anthropogenic emissions and reemissions from the legacy mercury accumulated in the oceans and soil reservoirs (Lindberg et al., 2007; Soerensen et al., 2010b). Transported in the atmosphere primarily in the form of less reactive, gaseous elemental mercury $(\mathrm{Hg}(0)$, or GEM), the principal process governing the transfer of mercury from the atmosphere to the oceans involves oxidation of $\mathrm{Hg}(0)$, because oxidized mercury (primarily $\mathrm{Hg}(\mathrm{II})$, but it may also include $\mathrm{Hg}(\mathrm{I})$ intermediates) is more prone to deposition than $\mathrm{Hg}(0)$ (Steffen et al., 2008; Strode et al., 2007). However, the mechanism of $\mathrm{Hg}(0)$ oxidation in the marine boundary layer (MBL) and its subsequent removal are not well known, particularly in the tropical oceans (Strode et al., 2007; Soerensen et al., 2010a).

Mercury dynamics in the tropical MBL is of interest as the upwelling of colder and nutrient-rich waters in these regions is known to be associated with enhanced mercury evasion from the oceans, presumably due to phytoplankton's 


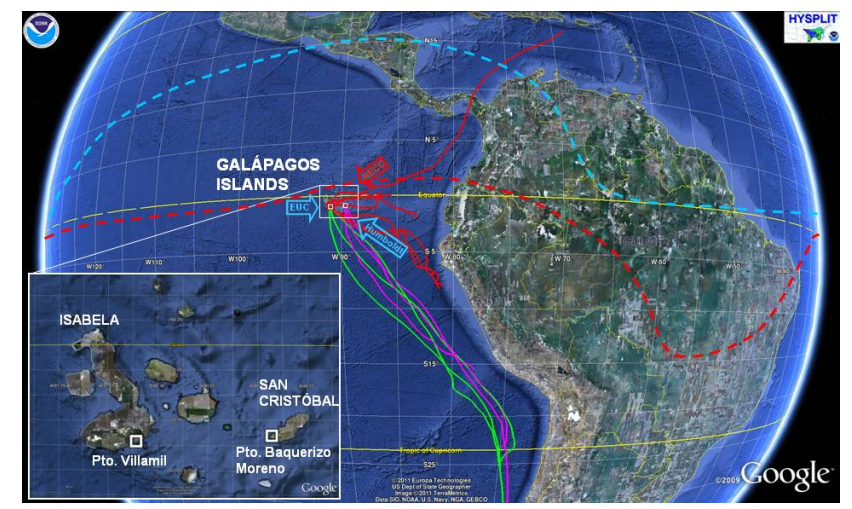

Fig. 1. Location map showing the oceanic and atmospheric circulation systems influencing the Galápagos archipelago. A selection of typical five-day back-trajectories calculated with the HYSPLIT (http://ready.arl.noaa.gov/HYSPLIT.php) Lagrangian integrated trajectory model are shown in red (March 2011), green (June 2011) and violet (October 2011). Arrows refer to major oceanic currents: the North Equatorial Countercurrent (NECC), Humboldt Current and Equatorial Undercurrent (EUC). Dashed lines indicate the approximate position of the Inter-Tropical Convergence Zone (ITCZ) in January (red) and July (light blue).

conversion of seawater $\mathrm{Hg}(\mathrm{II})$ to $\mathrm{Hg}(0)$ (Fitzgerald et al., 1984; Kim and Fitzgerald, 1986), but can also be due to photochemical reduction of seawater $\mathrm{Hg}$ (II) (Soerensen et al., 2010b, 2013). Major discrepancies, however, exist in the magnitude and fate of this re-emitted mercury. For instance, while one ship-based study reported a very high spike in the $\mathrm{Hg}(0)$ concentration in the MBL when over the upwelling region in the equatorial Pacific Ocean (Fitzgerald et al., 1984), no such increase in $\mathrm{MBL} \operatorname{Hg}(0)$ was found in subsequent studies (Kim and Fitzgerald, 1986; Soerensen et al., 2010a). Continuous monitoring of total gaseous mercury at a tropical Atlantic coastal site in Suriname did not detect any mercury evasion signals (Muller et al., 2012). Global mercury modelling has also resulted in highly contradictory estimates: an earlier model suggested that oceanic mercury emissions are largest in the tropics (Strode et al., 2007), but the net oceanic mercury emission from the tropical ocean was much less in a more recent estimate (Soerensen et al., 2010b).

Measurements of reactive gaseous mercury (RGM; primarily gaseous $\mathrm{Hg}(\mathrm{II})$ ) in the polar (Simpson et al., 2007; Steffen et al., 2008) to sub-tropical MBL (Laurier et al., 2003; Laurier and Mason, 2007; Obrist et al., 2011) and global mercury transport modelling (Holmes et al., 2010; Soerensen et al., 2010b) have suggested that the oxidation of $\operatorname{Hg}(0)$ in the MBL is primarily by atomic bromine $(\mathrm{Br})$, which is produced photolytically from $\mathrm{Br}$-containing compounds and through the $\mathrm{Br} / \mathrm{BrO}$ cycle involving tropospheric $\mathrm{O}_{3}$ (Saiz-Lopez and von Glasow, 2012). The currently held bromine-induced elemental mercury oxidation scheme (reactions R6-R9, Table 1) is thought to involve a $\mathrm{Hg}(\mathrm{I})$ intermediate $\mathrm{HgBr}$ (Goodsite et al., 2004, 2012; Holmes et al.,
2010). This scheme is favoured at colder temperatures in the polar regions, where the $\mathrm{HgBr}$ intermediate formed is stable enough to undergo further oxidation to $\mathrm{Hg}$ (II) (Goodsite et al., 2004, 2012). The contribution of bromine to $\mathrm{Hg}(\mathrm{I})$-to$\mathrm{Hg}$ (II) oxidation in the tropical MBL is, however, expected to be of lesser importance, since reactive bromine concentrations are generally low in the tropical regions (Theys et al., 2011) and since the $\mathrm{HgBr}$ intermediate tends to dissociate readily under warm temperatures (Goodsite et al., 2004, 2012; Dibble et al., 2012). Gas-phase $\mathrm{O}_{3}, \mathrm{OH}, \mathrm{HO}_{2}$, $\mathrm{H}_{2} \mathrm{O}_{2}$, and $\mathrm{NO}_{3}$ are all capable of oxidizing $\mathrm{Hg}(0)$ (e.g. reactions R1-R5 in Table 1) (Lin and Pehkonen, 1999; Dibble et al., 2012); however, it is generally thought that they play a negligible role in the observed production of RGM in the troposphere (Holmes et al., 2010) because their bonding with $\mathrm{Hg}(0)$ is either too weak or the reactions are too slow (Dibble et al., 2012).

An indication that bromine atoms may not be the only important oxidant for mercury in the tropical MBL can be observed in a recent round-the-globe cruise study (Soerensen et al., 2010a). Although generally low, the peak RGM concentrations at a few sites in the MBL of the tropical Atlantic and Pacific oceans were similar to those observed in the subtropical and temperate regions (Soerensen et al., 2010a). As the concentrations of atomic chlorine in the MBL are very low $\left(\leq 10^{4}\right.$ atoms $\mathrm{cm}^{-3}$ ) (Platt et al., 2004), one plausible candidate oxidant would be atomic iodine (I), which is predicted to aid in rapid oxidation of the $\mathrm{HgBr}$ intermediate (reaction R10 in Table 1) (Goodsite et al., 2004, 2012). Indeed, a role of iodine-containing species in RGM formation has been implied by modelling studies in the polar regions (Saiz-Lopez et al., 2008; Calvert and Lindberg, 2004), but has not been experimentally confirmed or quantified. Quantum chemical calculations have recently suggested that the $\mathrm{HgBr}$ intermediate could also be further oxidized in the presence of other free radicals such as $\mathrm{NO}_{2}, \mathrm{HO}_{2}, \mathrm{ClO}$, and $\mathrm{BrO}$ (reactions R12-R16 in Table 1) (Dibble et al., 2012).

As part of the Climate and HAlogen Reactivity tropicaL Experiment (CHARLEX) (Gómez Martín et al., 2013), a year-round field campaign was carried out in 2011 at the Galápagos Islands to measure $\mathrm{Hg}(0)$, oxidised mercury (RGM, and particulate mercury or $\mathrm{Hg}_{\mathrm{P}}$ ), along with $\mathrm{O}_{3}$, halogen oxides (BrO and IO) and $\mathrm{NO}_{2}$, in the tropical Pacific MBL. Different from ship-based studies where each station was only measured for a short period of time (Soerensen et al., 2010a), the CHARLEX campaign provided an opportunity to observe mercury species at a fixed location for an extended period of time, allowing detailed examination of the diurnal and seasonal variations. 
Table 1. Gas-phase mercury-halogen reactions used in the photochemical box model.

\begin{tabular}{|c|c|c|}
\hline Reaction & ate constant $(1 \mathrm{~atm}) \mathrm{cm}^{3}$ molecule ${ }^{-1} \mathrm{~s}^{-1}$ & Reference \\
\hline \multicolumn{3}{|l|}{ Direct oxidation scheme } \\
\hline $\begin{array}{l}\text { (R1) } \mathrm{Hg}^{0}+\mathrm{O}_{3} \rightarrow \mathrm{Hg}^{\mathrm{II}} \mathrm{O}+\mathrm{O}_{2} \\
\text { (R2) } \mathrm{Hg}^{0}+\mathrm{OH} \rightarrow \mathrm{Hg}^{\mathrm{II}} \\
\text { (R3) } \mathrm{Hg}^{0}+\mathrm{Br}_{2} \rightarrow \mathrm{Hg}^{\mathrm{II}} \mathrm{Br}_{2}^{\mathrm{a}} \\
\text { (R4) } \mathrm{Hg}^{0}+\mathrm{BrO} \rightarrow \mathrm{Hg}^{\mathrm{II}} \mathrm{O}+\mathrm{Br} \\
\left(\text { R5) } \mathrm{Hg}^{0}+\mathrm{ClO} \rightarrow \mathrm{Hg}^{\mathrm{II}} \mathrm{O}+\mathrm{Cl}\right.\end{array}$ & $\begin{array}{l}3 \times 10^{-20} \\
3.55 \times 10^{-14} e^{-2440 / R T} \\
9.0 \times 10^{-17} \\
1 \times 10^{-15} \\
1 \times 10^{-17}\end{array}$ & $\begin{array}{l}\text { Hall (1995) } \\
\text { Pal and Ariya (2004) } \\
\text { Ariya et al. (2002) } \\
\text { Raofie and Ariya (2003) } \\
\text { Subir et al. (2011) }\end{array}$ \\
\hline \multicolumn{3}{|l|}{ Two-step oxidation scheme } \\
\hline $\begin{array}{l}\text { (R6) } \mathrm{Hg}^{0}+\mathrm{Br} \rightarrow \mathrm{Hg}^{\mathrm{I}} \mathrm{Br} \\
\text { (R7) } \mathrm{Hg}^{\mathrm{I}} \mathrm{Br} \rightarrow \mathrm{Hg}^{0}+\mathrm{Br} \\
\text { (R8) } \mathrm{Hg}^{\mathrm{I}} \mathrm{Br}+\mathrm{OH} \rightarrow \mathrm{Hg}^{\mathrm{II}} \mathrm{BrOH} \\
\text { (R9) } \mathrm{Hg}^{\mathrm{I}} \mathrm{Br}+\mathrm{Br} \rightarrow \mathrm{Hg}^{\mathrm{II}} \mathrm{Br}_{2} \\
\text { (R10) } \mathrm{Hg}^{\mathrm{I}} \mathrm{Br}+\mathrm{I} \rightarrow \mathrm{BrHg}^{\mathrm{II}} \mathrm{I} \\
\text { (R11) } \mathrm{Hg}^{0}+\mathrm{Cl}(+\mathrm{Y}) \rightarrow \mathrm{Hg}^{\mathrm{I}} \mathrm{Cl}+\mathrm{Y}\end{array}$ & $\begin{array}{l}1.1 \times 10^{-12}(T / 298)^{-2.37} \\
1.2 \times 10^{10} e^{-8357 / T} \\
2.5 \times 10^{-10} \times(T / 298)^{-0.57} \\
2.5 \times 10^{-10} \times(T / 298)^{-0.57} \\
2.5 \times 10^{-10} \times(T / 298)^{-0.57} \\
2.2 \times 10^{-32} e^{680(1 / T-1 / 298)}\end{array}$ & $\begin{array}{l}\text { Goodsite et al. (2004) } \\
\text { Goodsite et al. (2004) } \\
\text { Goodsite et al. (2004) } \\
\text { Goodsite et al. (2004) } \\
\text { Goodsite et al. (2004) } \\
\text { Donohoue et al. (2005) }\end{array}$ \\
\hline \multicolumn{3}{|l|}{ Updated two-step oxidation scheme } \\
\hline $\begin{array}{l}\left(\mathrm{R}^{\prime}\right) \mathrm{Hg}^{0}+\mathrm{Br} \rightarrow \mathrm{Hg}^{\mathrm{I}} \mathrm{Br} \\
\left(\mathrm{R}^{\prime}\right) \mathrm{Hg}^{\mathrm{I}} \mathrm{Br} \rightarrow \mathrm{Hg}^{0}+\mathrm{Br} \\
\left(\mathrm{R}^{\prime}\right) \mathrm{Hg}^{\mathrm{I}} \mathrm{Br}+\mathrm{OH} \rightarrow \mathrm{BrHg}^{\mathrm{II}} \mathrm{OH} \\
\left(\mathrm{R}^{\prime}\right) \mathrm{Hg}^{\mathrm{I}} \mathrm{Br}+\mathrm{Br} \rightarrow \mathrm{Hg}^{\mathrm{II}} \mathrm{Br}_{2} \\
(\mathrm{R} 10 ') \mathrm{Hg}^{\mathrm{I}} \mathrm{Br}+\mathrm{I} \rightarrow \mathrm{BrHg}^{\mathrm{II}} \\
(\mathrm{R} 11) \mathrm{Hg}^{0}+\mathrm{Cl}(+\mathrm{Y}) \rightarrow \mathrm{Hg}^{\mathrm{I}} \mathrm{Cl}+\mathrm{Y} \\
(\mathrm{R} 12) \mathrm{Hg}^{\mathrm{I}} \mathrm{Br}+\mathrm{NO}_{2} \rightarrow \mathrm{BrHg}^{\mathrm{II}} \mathrm{NO}_{2} \\
(\mathrm{R} 13) \mathrm{Hg}^{\mathrm{I}} \mathrm{Br}+\mathrm{NO}_{2} \rightarrow \mathrm{BrHg}^{\mathrm{II}} \mathrm{ONO} \\
(\mathrm{R} 14) \mathrm{Hg}^{\mathrm{I}} \mathrm{Br}+\mathrm{HO}_{2} \rightarrow \mathrm{BrHg}^{\mathrm{II}} \mathrm{HO}_{2} \\
(\mathrm{R} 15) \mathrm{Hg}^{\mathrm{I}} \mathrm{Br}+\mathrm{BrO} \rightarrow \mathrm{BrHg}^{\mathrm{II}} \mathrm{OBr} \\
(\mathrm{R} 16) \mathrm{Hg}^{\mathrm{I}} \mathrm{Br}+\mathrm{IO} \rightarrow \mathrm{BrHg}^{\mathrm{II}} \mathrm{OI}\end{array}$ & $\begin{array}{l}3.7 \times 10^{-13}(T / 298)^{-2.76} \\
1.6 \times 10^{-9} e^{-7801 / T} \times[\mathrm{M}] \\
6.33 \times 10^{-11} \\
6.33 \times 10^{-11} \\
6.28 \times 10^{-11} \\
2.2 \times 10^{-32} e^{680(1 / T-1 / 298)} \\
2.81 \times 10^{-11} \\
5.82 \times 10^{-11} \\
8.2 \times 10^{-11} \\
1.09 \times 10^{-10} \\
4.9 \times 10^{-11}\end{array}$ & $\begin{array}{l}\text { Goodsite et al. (2012) } \\
\text { Dibble et al. (2012) } \\
\text { Calculated }^{\text {b }} \\
\text { Calculated }^{b} \\
\text { Calculated }^{\text {b }} \\
\text { Donohoue et al. (2005) }_{\text {Calculated }^{b}} \\
\text { Calculated }^{b} \\
\text { Calculated }^{b} \\
\text { Calculated }^{b} \\
\text { Calculated }^{\mathrm{c}}\end{array}$ \\
\hline \multicolumn{3}{|l|}{ Henry's law constant (equilibrium) } \\
\hline$(\mathrm{R} 17) \mathrm{HgCl}_{2}=\mathrm{HgCl}_{2}(\mathrm{aq})^{\mathrm{d}}$ & $1.4 \times 10^{6} \mathrm{M} \mathrm{atm}^{-1}$ & Hedgecock and Pirrone (2001) \\
\hline \multicolumn{3}{|c|}{$\begin{array}{l}{ }^{\mathrm{a}} \mathrm{HgBr}_{2} \text { refers to } \mathrm{BrHgBr} \text {. The geometries of these } \mathrm{BrHgX} \text { species }\left(\mathrm{X}=\mathrm{Br}, \mathrm{OH}, \mathrm{NO}_{2}, \mathrm{HO}_{2} \text { ) are reported by Dibble et al. (2012). }\right. \\
{ }^{\mathrm{b}} \mathrm{Calculations} \text { at } 298 \mathrm{~K} \text { and } 1 \text { atm using ab initio data from Dibble et al. (2012). The inverse Laplace transform (Davies et al., 1986; Robertson et al., 1995) } \\
\text { version of the MESMER algorithm (http://sourceforge.net/projects/mesmer) (Glowacki et al., 2012) is employed. High-pressure limit rate coefficients are } \\
\text { estimated from long-range capture rates. Relevant parameters for the master equation calculations are: }<\Delta E_{\text {down }}>=300 \mathrm{~cm}^{-1}, \sigma=3 \AA, \varepsilon / \kappa=250 \mathrm{~K} \text {. } \\
\text { Note that the rate coefficient for (R9') is in reasonable agreement with the lower limit obtained from quasiclassical trajectory calculations by Balavanov et } \\
\text { al. (2005). } \\
{ }^{\mathrm{c}} \text { Not included in the study by Dibble et al. (2012). Calculations at } 298 \mathrm{~K} \text { and } 1 \mathrm{~atm} \text { using our own ab initio data at the same level of theory considered by } \\
\text { Dibble et al. (2012). } \\
{ }^{\mathrm{d}} \text { We assume the same solubility for all halogen complexes of } \mathrm{Hg} \text { (e.g. } \mathrm{HgCl}_{2}, \mathrm{HgBr}_{2}, \mathrm{HgBrI} \text { ) (Hedgecock and Pirrone, 2001). }\end{array}$} \\
\hline
\end{tabular}

\section{Experimental}

\subsection{Site description}

The CHARLEX field campaign was carried out from February to October 2011 on the Galápagos Islands to investigate halogen and mercury chemistry in the tropical Pacific MBL. Details of the sampling sites and the general oceanic and atmospheric circulation systems around the Galápagos Islands can be found elsewhere (Gómez Martín et al., 2013). Briefly, the southern shores of the archipelago receive the prevailing southeasterly trade winds directly off the ocean for $\sim 90 \%$ of the time, carrying air masses that have been over the open ocean for many days (Fig. 1). The associated Humboldt cold oceanic current induces the cool and dry season from June to November. The moisture evaporating from the sea is trapped in an inversion layer (300 to $800 \mathrm{~m}$ above sea level) creating stratus clouds, which are intercepted by the southern volcanic slopes of the islands where precipitation is received in the form of mist rain ("garúa"), while lowland areas remain dry and relatively cold.

During the northern winter, the Inter-Tropical Convergence Zone edge migrates south, close to the northernmost islands, weakening the southeasterly trade winds and shifting the dominant oceanic current to the North Equatorial Countercurrent. For a few weeks northeasterlies can reach 
even the south of the archipelago as shown by the red backtrajectories in Fig. 1. Warmer waters cause the cold season inversion layer to break up. Thus, the hot season is characterized by typical tropical weather, with clear skies alternating with convection and occasionally heavy orographic rainfall.

Characteristic features of the Galápagos Islands are the exceptional amplitude of the seasonal variability of the sea surface temperature (SST) and the existence of spatially consistent, temporally variable areas with elevated primary productivity (salinity $>34,[\mathrm{Chl} a]>0.4 \mathrm{mg} \mathrm{m}^{-3}, \mathrm{SST}<24^{\circ} \mathrm{C}$ ) related to topographic upwelling from the Equatorial Undercurrent into surface waters (Schaeffer et al., 2008).

\subsection{Measurements}

Real-time concentrations of $\mathrm{Hg}(0)$, ozone, $\mathrm{BrO}$, $\mathrm{IO}$ and $\mathrm{NO}_{2}$ were measured throughout most of the 9-month duration, whereas the concentrations of RGM and $\mathrm{Hg}_{\mathrm{P}}$ were measured in three different seasons: 23 February-29 March, 10-19 June, and 10-26 October. From February to June 2011, the monitoring was performed at a waterside platform in Puerto Villamil, Isabela Island $\left(0^{\circ} 57^{\prime} \mathrm{S}, 90^{\circ} 58^{\prime} \mathrm{W}\right)$. The station was subsequently relocated, from July to October 2011, to the local WMO station (S/N 84008) in Puerto Baquerizo Moreno, San Cristóbal Island $\left(0^{\circ} 54^{\prime} \mathrm{S}, 89^{\circ} 36^{\prime} \mathrm{W}\right)$. Both sites are located south of the equatorial front and are under the southeast trade wind regime, with January to April being the hot and wet season (Gómez Martín et al., 2013).

Atmospheric concentrations of $\mathrm{Hg}(0), \mathrm{RGM}$ and $\mathrm{Hg}_{\mathrm{P}}$ were measured using an automated Tekran system comprised of Model 1130 and 1135 speciation units with a Model 1102 air dryer and a 2537B mercury vapour analyser, following established procedures (Steffen et al., 2012; Soerensen et al., 2010a). The system was configured to measure $\mathrm{Hg}(0)$ with a temporal resolution of $5 \mathrm{~min}$ and RGM and $\mathrm{Hg}_{\mathrm{P}}$ every $3 \mathrm{~h}$. RGM was operationally defined as the $\mathrm{Hg}$ that was retained on a $\mathrm{KCl}$-coated quartz annular denuder, and $\mathrm{Hg}_{\mathrm{P}}$ as the $\mathrm{Hg}$ that passed through the $\mathrm{KCl}$-coated denuder and retained on a downstream $2.5 \mu \mathrm{m}$ quartz filter. All mercury data are reported in units of nanograms or picograms per standard cubic metre under the standard conditions of $0^{\circ} \mathrm{C}$ and $1 \mathrm{~atm}$. Extensive laboratory and field tests have established that the detection limit (DL) for $\mathrm{Hg}(0)$ measured by this technique is better than $0.10 \mathrm{ng} \mathrm{m}^{-3}$ for $\mathrm{Hg}(0)$ (Tekran, 2011). Based on the sampling volumes, the DL for RGM and $\mathrm{Hg}_{\mathrm{P}}$ was estimated to be better than $0.42 \mathrm{pg} \mathrm{m}^{-3}$. Calibration of the system was carried out daily with the built-in internal mercury permeation source within the Tekran 2537B detector, and monthly with manual injections of an external mercury source (Tekran 2505). No calibration standards were available for RGM and $\mathrm{Hg}_{\mathrm{P}}$, but the $1 \sigma$ precision for $\mathrm{RGM}$ and $\mathrm{Hg}_{\mathrm{P}}$ was about $15 \%$ (Landis et al., 2002). Other QA/QC procedures followed the standard procedures developed by Environment Canada, and are comparable with those by the Atmospheric Mercury Network (AMNet) of the USA (Steffen et al., 2012).
While the same Tekran-based mercury speciation technique has been widely used by Environment Canada, the Atmospheric Mercury Network (AMNet) of the USA, and the Global Mercury Observation System (GMOS) of the European Union, it should be noted that recent studies, published after the completion of the field programme of this study, have shown that the KCl-coated denuder in the Tekran technique does not efficiently collect all gaseous oxidized mercury (GOM) compounds (e.g. $\mathrm{HgCl}_{2}, \mathrm{HgBr}_{2}, \mathrm{HgO}$ ), and thus could underestimate reactive mercury by up to several fold (Gustin et al., 2013; Huang et al., 2013). Therefore, RGM values reported in this study should be considered as the lower limits of GOM until the new generation of in situ measurement techniques (e.g. Ambrose et al., 2013) is applied at the study site. For this reason, we also retain the widely used terminology RGM, instead of GOM, to flag that our data are only comparable with the existing Tekran-based literature results, and to avoid confusion with GOM values that are being generated through new techniques (e.g. Ambrose et al., 2013).

The concentrations of $\mathrm{BrO}$ and $\mathrm{IO}$ were measured by a long-path differential optical absorption spectroscopy (LPDOAS) (Plane and Saiz-Lopez, 2006) and a Multi Axis DOAS (MAX-DOAS) (Hönninger et al., 2004) instrument at a temporal resolution of $1 \mathrm{~h}$, as detailed in Gómez Martín et al. (2013). In brief, both instruments were shifted between two wavelength regions for detecting $\mathrm{BrO}, \mathrm{HCHO}$ and $\mathrm{O}_{4}(336-379 \mathrm{~nm})$ or $\mathrm{IO},(\mathrm{CHO})_{2}$ and $\mathrm{O}_{4}(415.6-460.3 \mathrm{~nm})$. The collected spectra were analysed using the QDOAS software (Fayt et al., 2011). The LP-DOAS mixing ratio DLs $(2 \sigma)$ were 0.5 parts per trillion by volume (pptv) for $\mathrm{BrO}$ and $1 \mathrm{pptv}$ for IO. The MAX-DOAS differential slant column density (dSCD) DLs $(1 \sigma)$ were $1 \times 10^{13}$ molecule $\mathrm{cm}^{-2}$ for $\mathrm{BrO}$ and $0.5 \times 10^{13} \mathrm{molec}^{-2}$ for IO, which convert to $\sim 1 \mathrm{pptv}$ and $0.2 \mathrm{pptv}$ respectively using radiative transfer calculations (Gómez Martín et al., 2013).

In situ measurements of $\mathrm{O}_{3}$ were made using a standard UV absorption instrument (2B technologies, Model 205) at a temporal resolution of 10 min with a DL of 2 parts per billion by volume (ppbv), and $\mathrm{NO}_{2}$ by a chemiluminescence analyser (Teledyne 200EU) with a DL of 50 pptv. Continuous measurements of relative humidity $(\mathrm{RH})$, temperature, wind speed and direction, and other meteorological parameters were also made at a temporal resolution of 2 min by two weather stations (Davis WeatherLink Vantage), and a global radiometer (Kipp \& Zonen CPM11). Daily averaged SST, CDOM, and Chlorophyll $a(\mathrm{Chl} a)$ recorded by MODIS (Aqua) for the complete measurement period were obtained from the Ocean Color website (http://oceancolor.gsfc.nasa. gov) and averaged in a $3^{\circ}$-wide box extending $1^{\circ}$ from the location of the measurements to the south. Direct in situ measurement of SST was carried out at San Cristóbal every $6 \mathrm{~h}$. 


\subsection{Photochemical box modelling}

The evolution of mercury species in the MBL was studied by a photochemical box model using the halogen chemical scheme containing iodine and bromine gas phase and heterogeneous uptake reactions (Mahajan et al., 2010). For the mercury oxidation schemes, Holmes et al. $(2009,2010)$ considered both a slow, direct $\mathrm{Hg}(0)$ to $\mathrm{Hg}$ (II) pathway and a faster, two-step pathway involving the formation of $\mathrm{HgBr}$ followed by further oxidation by $\mathrm{Br}$ or $\mathrm{OH}$ (iodine was not included in their modelling). The latter scheme was primarily based on rate constants estimated from ab initio quantum calculations (Goodsite et al., 2004). However, the key thermal dissociation rate of $\mathrm{HgBr}$ has recently been found erroneous, with revised values at $1 \mathrm{~atm}$ and $298 \mathrm{~K}$ up to 20 times faster than the previous estimation (Goodsite et al., 2012; Dibble et al., 2012). Furthermore, other trace gases could also act as oxidants of the $\mathrm{HgBr}$ intermediate according to recent $\mathrm{ab}$ initio quantum calculations of bonding energies of $\mathrm{X}-\mathrm{HgBr}$ complexes ( $\left.\mathrm{X}=\mathrm{NO}_{2}, \mathrm{HO}_{2}, \mathrm{BrO}, \mathrm{ClO}\right)$ (Dibble et al., 2012). Therefore, three chemical pathways for mercury oxidation are evaluated with the photochemical model (Table 1): (i) direct oxidation of $\mathrm{Hg}(0)$ to $\mathrm{Hg}(\mathrm{II})$ by $\mathrm{O}_{3}$ (R1), $\mathrm{OH}(\mathrm{R} 2), \mathrm{Br}_{2}$ (R3), $\mathrm{BrO}$ (R4), and $\mathrm{ClO}$ (R5); (ii) a two-step mechanism with the original chemistry scheme (i.e. prior to the 2012 revision of the $\mathrm{HgBr}$ dissociation rate), where atomic bromine combines with $\mathrm{Hg}(0)$ to first form $\mathrm{Hg}(\mathrm{I})$ (R6), which is then oxidised to $\mathrm{Hg}(\mathrm{II})$ by $\mathrm{OH}, \mathrm{Cl}, \mathrm{Br}$, and I (R7-R10). This is essentially the same as used in Holmes et al. (2009), with the exception of oxidation by atomic I, which was not considered in that study; and (iii) a two-step mechanism with an updated chemistry scheme including updated rate constants for reactions R6'-R10' (Goodsite et al., 2012; Dibble et al., 2012), as well as new aggregation reactions, computed in this study, involving $\mathrm{NO}_{2}$ (R12 and R13), $\mathrm{HO}_{2}$ (R14), $\mathrm{BrO}$ (R15), and IO (R16). To derive rate constants and thermal dissociation lifetimes for these reactions at $298 \mathrm{~K}$ and $1 \mathrm{~atm}$ from the ab initio data reported by Dibble et al. (2012), we used the Master Equation Solver for Multi-Energy well Reactions (MESMER) (Glowacki et al., 2012), in a similar fashion to the calculations performed by Goodsite et al. (2004) for $\mathrm{Br}+$ $\mathrm{HgBr}$. Partitioning of $\mathrm{HgCl}_{2}$ between the gaseous and aqueous phases is also included in the model (R17).

Entrainment of $\mathrm{Hg}(\mathrm{II})$ from the free troposphere is calculated according to parameterisation given in Holmes et al. (2009), which depends on the RGM concentration gradient between the MBL and the free troposphere. The entrainment velocity is considered to be $0.5 \mathrm{~cm} \mathrm{~s}^{-1}$ (Faloona et al., 2005) and the free tropospheric RGM concentration used for calculating the flux is $20 \mathrm{pg} \mathrm{m}^{-3}$. The sinks considered for $\mathrm{Hg}(\mathrm{II})$ are boundary layer ventilation (calculated in a similar way to the entrainment), sea salt aerosol uptake and dry deposition (deposition velocity of $0.46 \mathrm{~cm} \mathrm{~s}^{-1}$ ). Uptake of RGM on aerosols is determined by its Henry's law equilibrium constant $\left(K_{\mathrm{H}}\right)$, the rates of which are taken from
Lindqvist and Rodhe (1985), and the total aerosol volume. Note that the $K_{\mathrm{H}}$ values for bromine- and iodine-containing RGM compounds are considered to be the same as $\mathrm{HgCl}_{2}$ $\left(1.4 \times 10^{6} \mathrm{M} \mathrm{atm}^{-1}\right)$. The total lifetime of RGM in the MBL is calculated to be $4.8 \mathrm{~h}$. Wet deposition was not considered and data from rainy days have been filtered out to ensure wet deposition did not play a role.

The model is constrained with observed diurnal profiles of $\mathrm{NO}_{2}, \mathrm{O}_{3}, \mathrm{H}_{2} \mathrm{O}$ and aerosol surface area $(4.07 \times$ $10^{-7} \mathrm{~cm}^{2} \mathrm{~cm}^{-3}$ ), and $\mathrm{RH}$ along with other meteorological parameters (see Fig. S1 in the Supplement). The boundary layer height is assumed to be $1000 \mathrm{~m}$ and is typical of the height observed at the site using radiosonde/ozonesonde data (see Sect. 3.5 below). The prescribed mixing ratios of atomic chlorine $\left(5.5 \times 10^{-4}\right.$ pptv or $1.4 \times 10^{4}$ atoms $\left.\mathrm{cm}^{-3}\right)$ and calculated $\mathrm{OH}(0.2 \mathrm{pptv})$ at noon are consistent with the box model parameters used by Holmes et al. (2009). The daytime mixing ratios of $\mathrm{NO}_{2}$ were under the DL (50 pptv) throughout the campaign and are prescribed to be $40 \mathrm{pptv}$. The simultaneous rate equations are solved using the KPP 2.2.3 integrator (Sandu and Sander, 2006). Photodissociation frequencies are calculated offline using a two-stream radiation code (Thompson, 1984).

The simulations are also constrained with the observed $\mathrm{Hg}(0)$ diurnal profiles, and the total $\mathrm{Hg}(\mathrm{II})$ generated in different scenarios is then calculated. The model is likewise constrained with the MAX-DOAS observed IO mixing ratios, while the daytime $\mathrm{BrO}$ mixing ratio is considered to be equal to $0.2 \mathrm{pptv}$, consistent with the absence of $\mathrm{BrO}$ in the LP-DOAS at $1 \sigma$ DL and with low bromine levels from satellite estimates (Theys et al., 2011), and predictions by the large-scale CAM-Chem (Saiz-Lopez et al., 2012) and GEOS-CHEM (Holmes et al., 2010) chemistry models for the eastern Pacific. Note that sensitivity runs included 0.5 pptv BrO, according to the LP-DOAS detection limit. The $\mathrm{Br}$ atom concentration is calculated online in the model, which has a detailed description of bromine chemistry. The $\mathrm{BrO} / \mathrm{Br}$ ratio (on average about 10 during CHARLEX) is largely sensitive to the $\mathrm{O}_{3}$ concentration, which is constrained, giving higher confidence in the calculated $\mathrm{Br}$ atom concentration. The atomic iodine mixing ratios are calculated from the measured IO mixing ratios using the same chemical box model constrained with the observed $\mathrm{IO}, \mathrm{O}_{3}$ and $\mathrm{NO}_{2}$. In this clean environment, the partitioning between IO and I is mainly determined by the IO photolysis rate and the reaction between $\mathrm{I}$ and $\mathrm{O}_{3}$ to form back IO.

\section{Results and discussion}

\section{1 $\mathrm{Hg}(0)$ concentration in the tropical MBL}

As shown in Figs. 2 (entire campaign) and 3 (three intensive measurement periods), $\mathrm{Hg}(0)$ remained low $\left(1.08 \pm 0.17 \mathrm{ng} \mathrm{m}^{-3} \quad\right.$ (average \pm s.d.), $\quad$ range: $\quad 0.58$ 


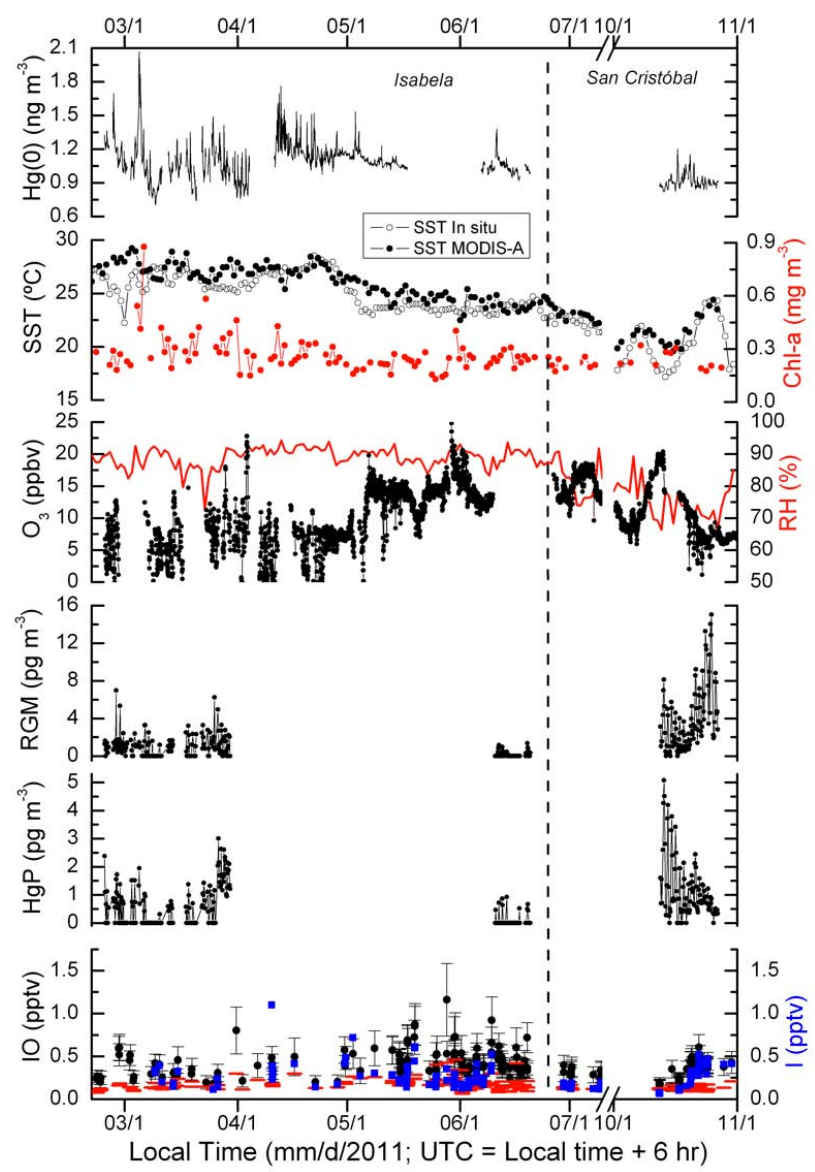

Fig. 2. Atmospheric mercury and related parameters over the Galápagos Islands. From top to bottom: atmospheric $\mathrm{Hg}(0)$ (hourly average), sea surface temperature (SST; daily average) and ocean surface $\mathrm{Chl} a$ (daily average), atmospheric marine boundary layer $\mathrm{O}_{3}$ (every $10 \mathrm{~min}$ ) and relative humidity (RH; daily average), reactive gaseous mercury (RGM) and particulate mercury ( $\mathrm{Hg}_{\mathrm{P}}$; every $3 \mathrm{~h}$ ), and IO (every $1 \mathrm{~h}$; detection limit is shown in red) and I atom (calculated from $\mathrm{IO}$ and $\mathrm{O}_{3}$ ) over the entire study period. The data before 1 July 2011 were obtained at Puerto Villamil on Isabela Island, and those after were from Puerto Baquerizo Moreno on San Cristóbal Island.

$\left.2.0 \mathrm{ng} \mathrm{m}^{-3} ; n=20236\right)$ throughout the campaign, and was markedly lower than the total gaseous mercury (which is dominated by $\mathrm{Hg}(0))$ measured at a tropical Atlantic coastal site (Muller et al., 2012). The $\mathrm{Hg}(0)$ levels, especially during evenings, showed considerable seasonal variations (Figs. 2-4): they were the highest and most variable from February to May, decreased in June, and became the lowest and least variable in October. Contrary to an earlier ship-based study (Fitzgerald et al., 1984) but similar to two subsequent studies (Soerensen et al., 2010a; Kim and Fitzgerald, 1986), we did not observe sustained high $\mathrm{Hg}(0)$ concentrations that would be indicative of persistently enhanced biotic mercury evasion from the upwelling region in the equatorial Pacific Ocean.

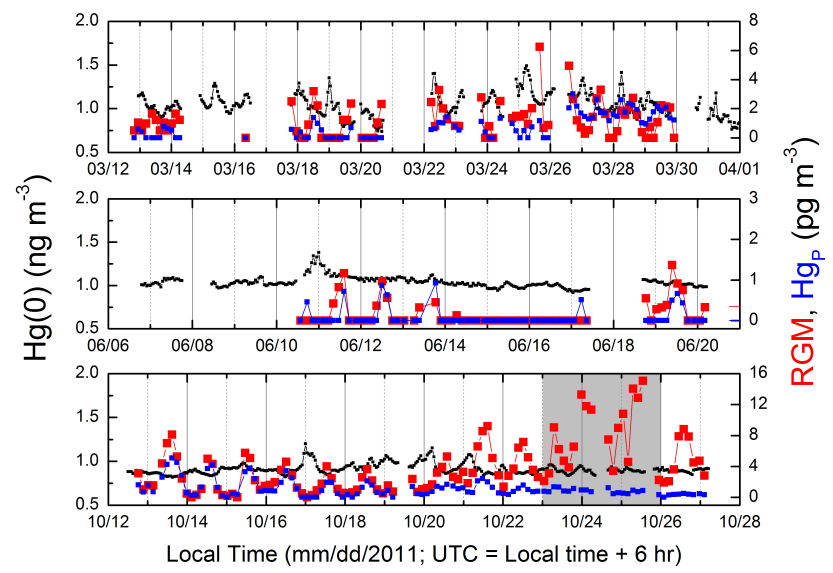

Fig. 3. Atmospheric $\mathrm{Hg}(0)$, reactive gaseous mercury (RGM) and particulate mercury $\left(\mathrm{Hg}_{\mathrm{P}}\right)$ in the $\mathrm{MBL}$ on the Galápagos Islands during three different periods in 2011. The data for March and June were obtained from Puerto Villamil on Isabela Island, and those for October were from Puerto Baquerizo Moreno on San Cristóbal Island. The temporal resolution was $5 \mathrm{~min}$ for $\mathrm{Hg}(0)(1 \mathrm{~h}$ averages are shown here) and $3 \mathrm{hr}$ for RGM and $\mathrm{Hg}_{\mathrm{P}}$. Shaded in grey is the period (23-25 October) when an unusual diurnal change in RGM was observed, which was most likely due to a localized and shortlived event.

This difference may be attributed to temporal and spatial variability in upwelling and in primary production (Kim and Fitzgerald, 1986). However, no statistically significant relationship was found between $\mathrm{Hg}(0)$ and surface Chl $a$ concentration during the 9-month study (Fig. 5a). Instead, daily averaged $\mathrm{Hg}(0)$ was significantly higher ( $p<0.001$; Mann-Whitney test) in the warmer months of February to June $\left([\mathrm{Hg}(0)]=1.10 \pm 0.13 \mathrm{ng} \mathrm{m}^{-3} ; \mathrm{SST}=\right.$ $\left.26.4 \pm 1.6^{\circ} \mathrm{C}\right)$ than in the colder month of October $([\mathrm{Hg}(0)]$ $\left.=0.91 \pm 0.04 \mathrm{ng} \mathrm{m}^{-3} ; \mathrm{SST}=20.4 \pm 2.6^{\circ} \mathrm{C}\right)($ Fig. $5 \mathrm{~b})$, suggesting oceanic $\mathrm{Hg}$ evasion varies seasonally with SST, most probably due to the variation in photolytic reduction of seawater $\mathrm{Hg}$ (II) (Soerensen et al., 2010b, 2013).

\subsection{Enhanced production of $\mathrm{Hg}(\mathrm{II})$}

Mean concentrations of RGM and $\mathrm{Hg}_{\mathrm{P}}$ were comparable with ship-borne measurements in the MBL of the tropical Atlantic and Pacific oceans (Soerensen et al., 2010a), though much lower when compared with those occurring during polar mercury depletion events (Steffen et al., 2008), and showed seasonal variability, with the highest monthly concentrations in October $\left(\mathrm{RGM}=3.8 \pm 3.4 \mathrm{pg} \mathrm{m}^{-3}, \mathrm{Hg}_{\mathrm{P}}=\right.$ $\left.1.1 \pm 1.1 \mathrm{pg} \mathrm{m}^{-3}\right)$, followed by February-March $(\mathrm{RGM}=$ $1.0 \pm 1.2 \mathrm{pg} \mathrm{m}^{-3}, \mathrm{Hg}_{\mathrm{P}}=0.6 \pm 0.7 \mathrm{pg} \mathrm{m}^{-3}$ ), and decreasing to below the detection limit in June (Figs. 3 and 4). Throughout most of the campaign (except for a 3-day period, 23-25 October, when unusual variations in RGM occurred; Fig. 3), the concentration of RGM showed a distinct diurnal cycle, with a rapid increase at sunrise, peaking at midday and 


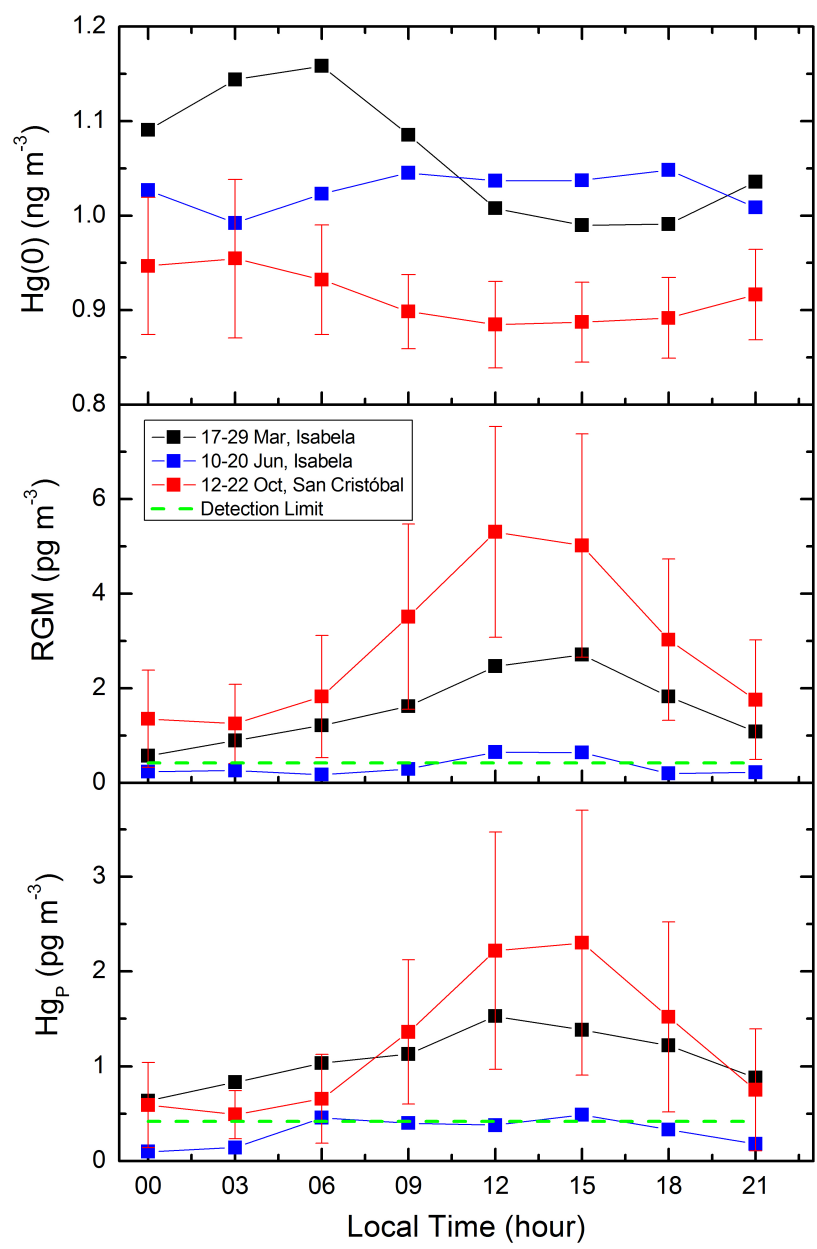

Fig. 4. Diurnal variations ( $3 \mathrm{~h}$ average) in atmospheric $\mathrm{Hg}(0)$, reactive gaseous mercury (RGM) and particulate mercury $\left(\mathrm{Hg}_{\mathrm{P}}\right)$ measured on the Galápagos Islands over three different seasons. For simplicity, error bars (standard deviations) are shown only for the October data. Dashed lines show the respective detection limits.

declining through the afternoon (Fig. 4). $\mathrm{Hg}_{\mathrm{P}}$ closely followed a similar diurnal trend, although its peak concentration was lower.

The peak levels of RGM, up to $10 \mathrm{pg} \mathrm{m}^{-3}$ (most periods) (or $15 \mathrm{pg} \mathrm{m}^{-3}$ during the unusual 3-day period in October) observed in the tropical MBL, are consistent with those reported for some tropical Atlantic and Pacific Ocean sites (Soerensen et al., 2010a) and in the sub-tropical to mid-latitude regions (Laurier et al., 2003; Laurier and Mason, 2007; Soerensen et al., 2010a). This is surprising given that the $\mathrm{BrO}$ mixing ratios were always below the $2 \sigma$ detection limit of 0.5 pptv throughout the CHARLEX campaign.

With the use of the observed diurnal profiles of $\mathrm{Hg}(0), \mathrm{O}_{3}$, $\mathrm{H}_{2} \mathrm{O}, \mathrm{BrO}$, IO, and $\mathrm{NO}_{2}$, we calculated the RGM due to different oxidation mechanisms (Table 1) with a photochemical box model (Fig. 6). BrO was considered to range from 0.2 pptv (Saiz-Lopez et al., 2012; Holmes et al., 2010) to the
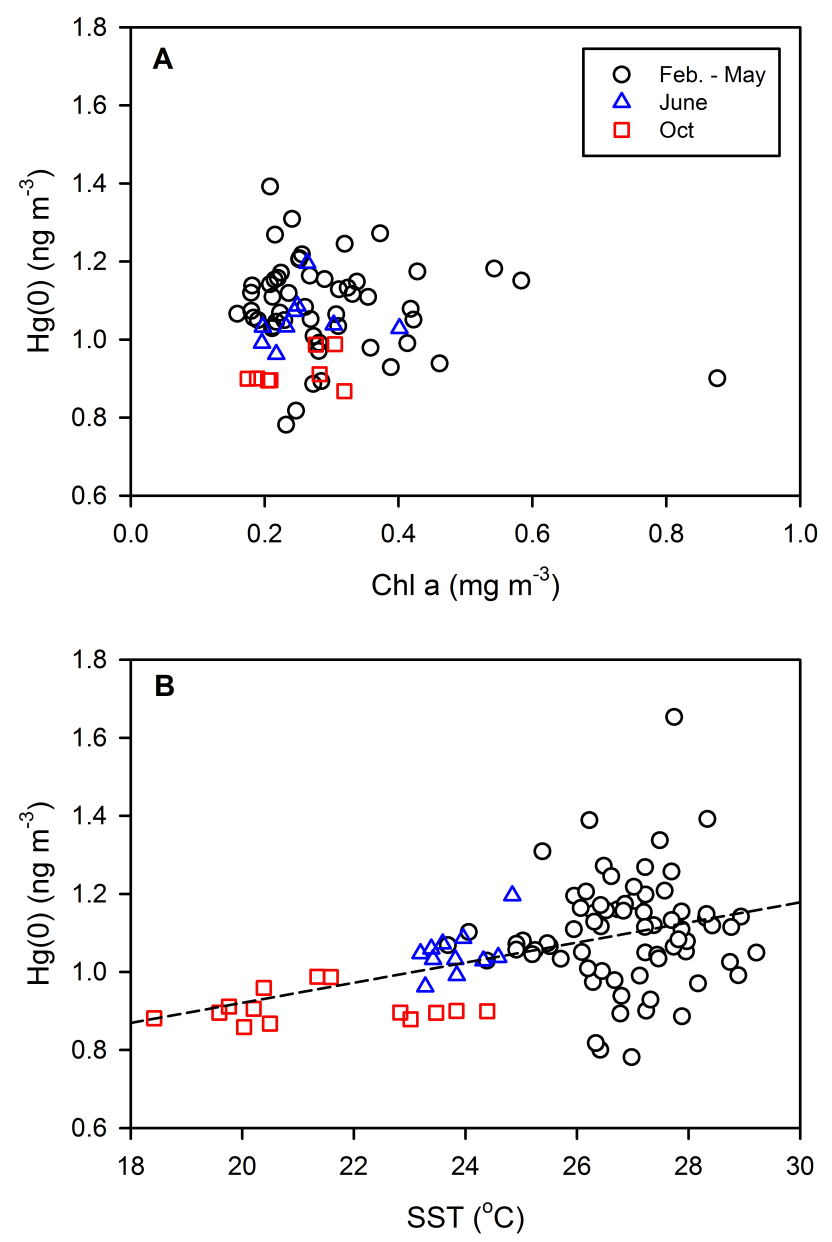

Fig. 5. Relationship between daily averaged concentrations of $\mathrm{Hg}(0)$ in the MBL and sea surface chlorophyll $a(\mathbf{A})$ and temperature (SST) (B).

0.5 pptv detection limit. The simulations based on the mechanism considered by Holmes et al. (2009) showed that the standard oxidation pathways involving $\mathrm{O}_{3}, \mathrm{OH}$, or $\mathrm{Br}$, or the combination of them, are not sufficient to explain the high RGM levels measured during CHARLEX. We estimate that the Br-alone scheme can account for no more than $50 \%$ of the RGM observed in October (Fig. 6a). As mentioned earlier, the RGM reported in this study is likely an underestimate of all GOM in the air (Gustin et al., 2013; Huang et al., 2013; Ambrose et al., 2013). An additional oxidant is thus needed to reproduce the high midday RGM concentrations. The diurnal variability of RGM clearly shows that this additional oxidant has to be generated by photochemistry.

\subsection{Potential oxidants of $\mathrm{Hg}(\mathrm{I})$ in the tropical MBL}

\subsubsection{Iodine}

In addition to bromine, atomic chlorine is suggested to chemically oxidize $\mathrm{Hg}(0)$ (Goodsite et al., 2004, 2012; Ariya et 

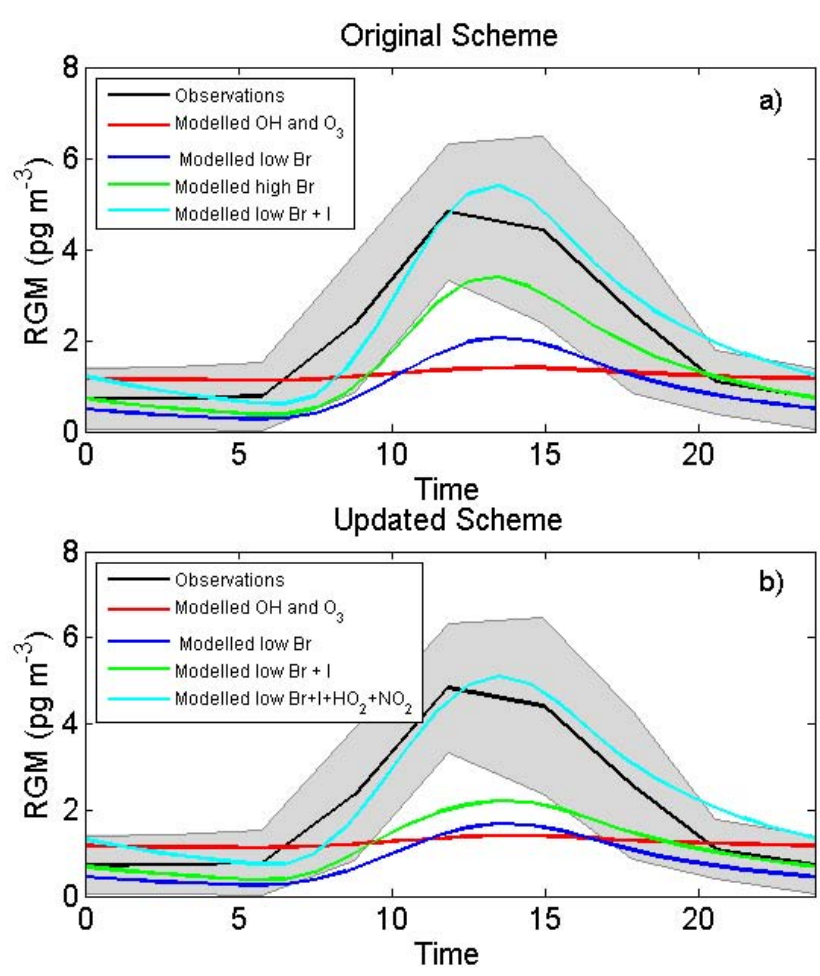

Fig. 6. Comparison of the average daily profile of reactive gaseous mercury (RGM) during October (grey area indicates the standard deviation of the data) with simulated profiles obtained by two different modelling approaches. (a) Modelled results from the original chemistry scheme according to Goodsite et al. (2004) and Holmes et al. (2009) under four different scenarios. Scenario 1: oxidation is assumed to result only from $\mathrm{OH}$ and $\mathrm{O}_{3}$ (red line). Scenario 2 adds bromine oxidation using a peak $\mathrm{BrO}$ of $0.2 \mathrm{pptv}$ (blue). Scenario 3 (green) assumes $\mathrm{BrO}$ to be at the detection limit of the DOAS instrument ( $0.5 \mathrm{pptv})$. Scenario 4 (cyan) shows a simulation with 0.2 pptv of $\mathrm{BrO}$ and the observed levels of IO, an average of 1 pptv during the daytime. (b) Modelled results using an updated chemistry scheme according to Goodsite et al. (2012) and Dibble et al. (2013). Peak daytime mixing ratios of the bonding molecules were $\mathrm{OH}=0.14$ pptv, $\mathrm{O}_{3}=10 \mathrm{ppbv}, \mathrm{Br}=0.08$ pptv, $\mathrm{I}=0.45 \mathrm{pptv}$, $\mathrm{NO}_{2}=40$ pptv, and $\mathrm{HO}_{2}=14$ pptv (see Fig. S1 for their diurnal profiles).

al., 2002). Although reaction with chlorine atoms is included in our calculations ( $\mathrm{R} 11$ in Table 1), due to low $\mathrm{Cl}$ atom concentrations in the MBL $\left(\leq 1.4 \times 10^{4}\right.$ atoms cm$\left.{ }^{-3}\right)$ (Platt et al., 2004), it does not have any significant effect on the fate of $\mathrm{Hg}$ and can thus not be responsible for the enhanced $\mathrm{Hg}$ (II) production observed in this study. For instance, a sensitivity analysis shows that increasing the $\mathrm{Cl}$ atom concentration tenfold from the predicted $1 \times 10^{4}$ atoms cm $^{-3}$ to $1 \times 10^{5}$ atoms cm$~^{-3}$ results in only $5 \%$ increase in the total RGM.

Unlike BrO, IO was consistently measured above the detection limit $(0.2 \mathrm{pptv})$ during the entire campaign, with a peak mixing ratio of 1 pptv (Fig. 2). Although the bromine re- action with mercury is the major initiating pathway in $\mathrm{Hg}(0)$ oxidation to form $\mathrm{HgBr}$, when an additional iodine oxidation reaction $(\mathrm{HgBr}+\mathrm{I} \rightarrow \mathrm{HgBrI})$ is added to the twostep reaction scheme ( $\mathrm{R} 10$ in Table 1$)$, using the measured IO concentrations, the modelled rate of RGM formation increases up to four times, which matches the observations well (Fig. 6a). The significant enhancement of mercury oxidation in the presence of iodine results from the higher I/IO ratio $\left(\sim 7.7 \times\left[\mathrm{O}_{3}\right]^{-1}\right.$, with $\left[\mathrm{O}_{3}\right]$ in ppbv) compared with that of $\mathrm{Br} / \mathrm{BrO}\left(\sim 2.4 \times\left[\mathrm{O}_{3}\right]^{-1}\right)$, due to faster photolysis of IO with respect to $\mathrm{BrO}$ (Saiz-Lopez et al., 2008). This, together with higher observed IO concentrations, results in an iodine atom concentration roughly an order of magnitude larger than bromine atoms.

\subsection{2 $\mathrm{NO}_{2}$ and/or $\mathrm{HO}_{2}$}

The results shown in Fig. 6a have been obtained using the original two-step oxidation mechanism (Goodsite et al., 2004; Holmes et al., 2009) with the additional contribution of iodine. As mentioned earlier, considerable uncertainty exists regarding this reaction scheme, since the theoretically derived rate constants for the second oxidation step have not been verified experimentally. Furthermore, recent studies (Dibble et al., 2012; Goodsite et al., 2012) found the thermal dissociation rate of $\mathrm{HgBr}$ derived by Goodsite et al. (2004) and used in subsequent modelling exercises (Holmes et al., 2009) to be in error by an order of magnitude. Dibble et al. (2012) also suggested that other trace gases such as $\mathrm{NO}_{2}$, $\mathrm{HO}_{2}, \mathrm{ClO}$ and $\mathrm{BrO}$ could act as oxidants of the $\mathrm{HgBr}$ intermediate. We have thus carried out further modelling with an updated two-step oxidation mechanism (Table 1). The bond energies of $\mathrm{X}-\mathrm{HgBr}\left(\mathrm{X}=\mathrm{NO}_{2}, \mathrm{HO}_{2}, \mathrm{BrO}\right.$, or $\left.\mathrm{ClO}\right)$ are similar to those of $\mathrm{BrHgBr}$ and $\mathrm{BrHgI}$ (Dibble et al., 2012), resulting in master equation-derived aggregation rates of the same magnitude $\left(2 \times 10^{-11}-1 \times 10^{-10} \mathrm{~cm}^{3}\right.$ molecule $\left.{ }^{-1} \mathrm{~s}^{-1}\right)$. Including the updated reaction rates for the formation and dissociation of $\mathrm{HgBr}$ and new reactions between $\mathrm{HgBr}$ and $\mathrm{NO}_{2}, \mathrm{HO}_{2}, \mathrm{BrO}$, and IO (Table 1), Fig. 6b shows that this scheme would also lead to modelled RGM levels similar to those observed. With this updated reaction scheme, bromine and iodine would only play a very minor role in the conversion of $\mathrm{Hg}(\mathrm{I})$ to $\mathrm{Hg}(\mathrm{II})$. Instead, the only way to generate RGM levels comparable with the observations reported here is to include the second-step reactions of $\mathrm{HgBr}$ with $\mathrm{NO}_{2}$ and $\mathrm{HO}_{2}$ (R12-R14). The much faster dissociation rate of $\mathrm{HgBr}$ (R7') in the updated chemistry scheme means that nothing else but $\mathrm{NO}_{2}$ and $\mathrm{HO}_{2}$, which have large enough concentrations, would further oxidise $\mathrm{HgBr}$ to RGM.

The modelling strongly reveals that some fundamental processes are missing in the currently accepted mercury oxidation mechanism and the two pathways suggested here would improve matching models with observed values of $\mathrm{Hg}(\mathrm{II})$. We suggest that the complete mercury oxidation 


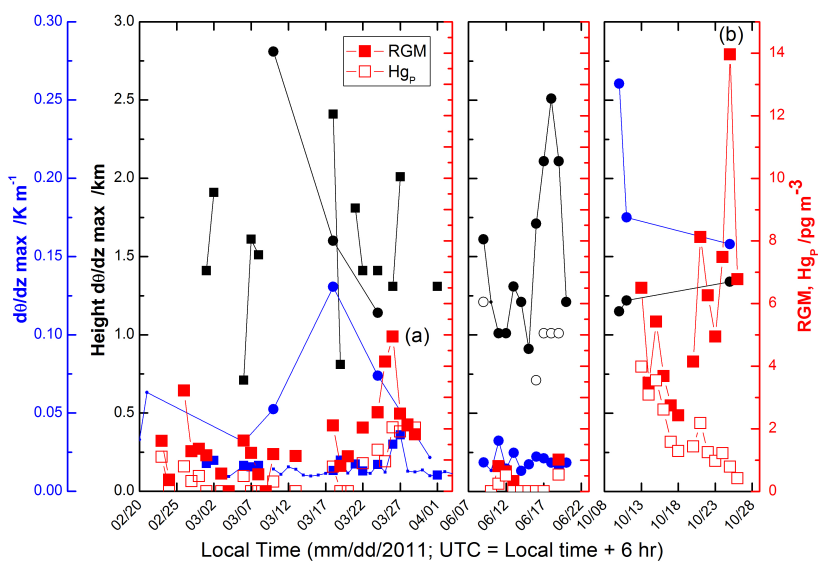

Fig. 7. Maximum lapse rate (blue) and height of maximum and second maximum lapse rates (solid and empty black circles respectively) obtained from radiosonde data during the CHARLEX campaign. The small blue circles (note corresponding missing black circles) indicate an uncapped boundary layer. In red: reactive gaseous mercury (RGM; full symbols) and particulate mercury ( $\mathrm{Hg}_{\mathrm{P}}$; empty symbols). The peak in RGM and $\mathrm{Hg}_{\mathrm{P}}$ at the end of March (a) is likely related to the disappearance of the inversion and the subsequent subsidence of free tropospheric air masses. The peak in RGM at the end of October was (b) most likely due to a localized and short-lived event.

scheme needs to be subjected to further laboratory and field studies to understand the major oxidation pathways.

\subsection{Influence of the free troposphere}

The highest concentrations of RGM were observed in October when there was a strong inversion in tropospheric temperature at a height of $\sim 1.2 \mathrm{~km}$ (Fig. 7), suggesting that the influence of free tropospheric RGM entrainment on RGM levels in the MBL was negligible. This, however, may not be the case in March when there was no inversion, with the exception of a period from 18 to 24 March when a weak inversion built up and then disappeared (Fig. 7). The disappearance of the inversion was followed by an increase in RGM and $\mathrm{Hg}_{\mathrm{P}}$ on 25 March. Therefore, the entrainment of free tropospheric RGM cannot be ruled out in March, although it is not the source of the high levels observed during October.

\subsection{RGM source and sinks in the tropical MBL: correlation analysis}

The rapid decrease in RGM to the background levels in early evenings indicates efficient removal by boundary layer ventilation, sea salt aerosol uptake and dry deposition (Holmes et al., 2009, 2010). Modelling studies of night-time RGM in the MBL have shown that both dry deposition and sea salt aerosol uptake increase with wind speed, and that aerosol uptake increases also at low RH (Holmes et al., 2009). A statistically significant correlation between RGM and wind speed was neither observed for the daily averaged data from the entire campaign, nor for the night-time averaged data from February to June (night-time meteorological data were not available for October). Instead, when considering the daily averaged data from the entire campaign, a statistically significant, negative correlation with RH was found (Fig. 8), explaining $68 \%$ of the variance. RGM was highest in October when the RH was lowest (Fig. 2). Inclusion in the regression fit of an extra term depending linearly on $\left[\mathrm{O}_{3}\right]^{-1}$ accounting for a halogen atom-driven RGM source (R9 and $\mathrm{R} 10)$ improved the fit, but its contribution is small $(6 \%)$ and mostly concentrated in the short-term variability during October (Fig. 8). This highlights the multivariate dependences of RGM sources and sinks and the shifting balance between them. The dominant role of RH suggests that RGM loss is controlled primarily by uptake onto sea salt aerosol, due to association with chloride (Holmes et al., 2009) or to the larger aerosol volumes; this is in agreement with a recent comparative study that shows $\mathrm{Hg}_{\mathrm{P}}$ is preferentially associated with sea salt at a marine site and with finer aerosols at a coastal site (Feddersen et al., 2012). The effect of RH on bromine activation on aerosol is not clear, with models suggesting an increase in halogen recycling with increasing $\mathrm{RH}$ due to faster uptake and recycling of reservoir species, leading to larger gas phase halogen concentrations (von Glasow et al., 2004). Note however that $\mathrm{BrO}$ mixing ratios were below the $0.5 \mathrm{pptv}$ detection limit during the entire campaign, with periods of significant variation in RH levels.

In the warm and wet season (February-March), a significant negative correlation between ozone and RH $(r=$ $-0.609, p<0.001)$, and between RGM and RH $(r=$ $-0.580, p=0.002$ ) was observed. In the tropical MBL the seasonal variability of ozone is controlled to a large extent by water vapour, showing a negative correlation due to $\mathrm{O}\left({ }^{1} \mathrm{D}\right)$ scavenging by $\mathrm{H}_{2} \mathrm{O}$. However, during the shorter measurement period in the cold and dry season (October), although the ozone levels were similar to those in the warm season (Fig. 2), they appeared decoupled from RH, while a positive dependence of RGM in $\left[\mathrm{O}_{3}\right]^{-1}(r=0.526, p=0.05)$ existed. Assuming that the RGM source is related to $\left[\mathrm{O}_{3}\right]^{-1}$ (e.g. the halogen atom-mediated second step in the old oxidation scheme, see Table 1), these relationships would indicate that RH not only controls the removal, but also indirectly influences the production of RGM. Thus, a sustained decrease in ozone in October $\left(\sim 1 \mathrm{ppb}\right.$ day $^{-1}$, Fig. 2$)$ seems to result in an enhancement of RGM sources, which is not balanced out by the low RH. By contrast, the strong coupling between $\mathrm{RH}$ and $\mathrm{O}_{3}$ would preclude an observable dependence of RGM on other processes during other periods. Finally, it is worth noting that the typical RGM daily cycle remained unaltered throughout several high $\mathrm{NO}_{2}$ events $(\sim 0.5 \mathrm{ppbv})$ related to shipping activities observed in the warm season. The $\mathrm{NO}_{2}$ and RGM daily averages or $12 \mathrm{~h}$ daytime averages do not show any significant correlation during the period when $\mathrm{NO}_{2}$ was measured, with $r=0.105(p=0.6)$ and $r=0.279$ 


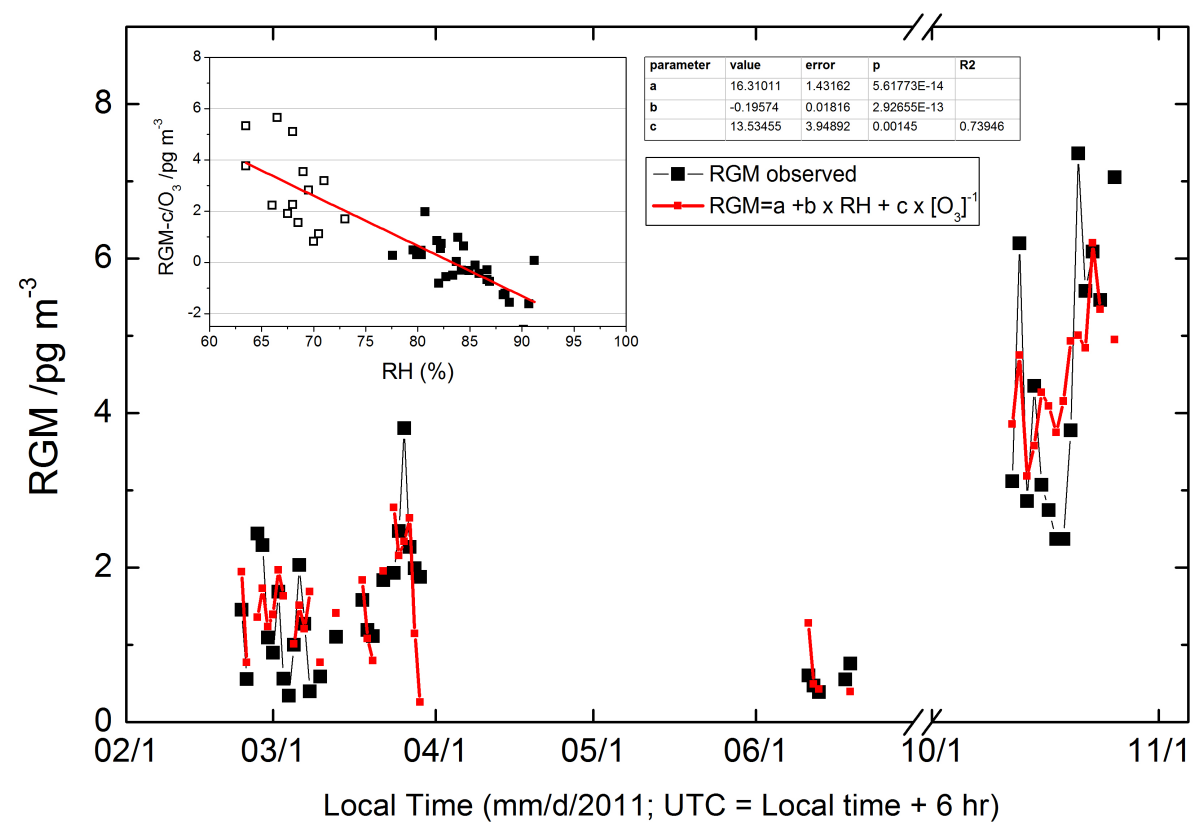

Fig. 8. Multilinear regression of reactive gaseous mercury $(\mathrm{RGM})$ vs. relative humidity $(\mathrm{RH})$ and $\left[\mathrm{O}_{3}\right]^{-1}$. The daily averaged observed data and the modelled data are shown in black and red respectively as a function of time. The inset shows the residual dependence of RGM on $\mathrm{RH}$ after removing the optimised $\left[\mathrm{O}_{3}\right]^{-1}$ contribution to RGM (full squares: March-June, open squares: October).

( $p=0.18)$ respectively. In October, no $\mathrm{NO}_{2}$ measurements were carried out, and therefore it is not possible to ascertain its potential role in enhanced RGM formation during that period. It must be noted that such lack of correlation during the warm season may not be indicative of $\mathrm{NO}_{2}$ not playing a role in mercury oxidation. One of the main reasons for this is the effect of $\mathrm{NO}_{2}$ on bromine chemistry. In the presence of larger levels of $\mathrm{NO}_{2}$, the reservoir bromine species that forms is $\mathrm{BrNO}_{3}$, which will limit the reactive bromine available for the formation of $\mathrm{HgBr}$.

Similar to RGM, there is a significant anti-correlation observed between $\mathrm{Hg}_{\mathrm{P}}$ and $\mathrm{RH}$ for the whole data set $(r=$ $-0.62, p<0.001)$, as well as between $\mathrm{Hg}_{\mathrm{P}}$ and RGM ( $r=$ $0.681, p=0.001$ ), further supporting the removal of RGM by its association with sea salt (Feddersen et al., 2012). The observed $\mathrm{Hg}_{\mathrm{P}} / \mathrm{RGM}$ ratio was $0.55 \pm 0.25$, whereas the only significant correlation of the $\mathrm{Hg}_{\mathrm{P}}$ / RGM ratio throughout the campaign was with the coloured dissolved organic matter $(\mathrm{CDOM})$ index $(r=0.482, p<0.01)$. If oceanic CDOM is considered as a proxy of the organic matter content of sea spray, this may be an indication of a reduction in the RGM to $\mathrm{Hg}_{\mathrm{P}}$ processing in aerosol due to a decrease in organic matter.

\subsection{Unusual diurnal cycles of RGM from 23-25 October}

While the generally observed mid-day peaking of RGM is more in line with the simulations shown in Fig. 6a or b, an unusual diurnal pattern was seen from 23-25 October (the shaded period in Fig. 3). During this short period, RGM peaked twice daily, one from midnight to early morning, and the other in the late afternoon. The peak RGM concentration reached as high as $16 \mathrm{pg} \mathrm{m}^{-3}$, the highest throughout the entire campaign. Night-time rising of RGM has been reported sporadically in the literature (Holmes et al., 2009; Soerensen et al., 2010a), though its cause has not been well studied. It could be speculated that elevated $\mathrm{NO}_{2}$ concentrations emitted over the $\sim 4 \mathrm{~km}$ strip of land, separating the ocean from the meteorological station at San Cristobal, could have enhanced the RGM levels via (R12) and (R13). Unfortunately, $\mathrm{NO}_{2}$ was not monitored during the last 15 days of the campaign, and therefore, this possibility could not be tested. However, as mentioned above, sustained high levels of $\mathrm{NO}_{2}$ are not compatible with the low $\mathrm{O}_{3}$ mixing ratios observed. Since the unusual RGM diurnal pattern in this study started and ended abruptly, lasting only three days, and since $\mathrm{Hg}_{\mathrm{P}}$ did not follow the same pattern, we hypothesize that it could result from a localized condition under which the RGM taken up by sea salt aerosols did not immediately deposit into the ocean and was subsequently re-emitted from the aerosols to the MBL.

\section{Conclusions}

The detection of enhanced $\mathrm{Hg}$ (II) production over the tropical MBL suggests that modelling based on known oxidation pathways (e.g. by $\mathrm{Br}, \mathrm{O}_{3}$, and $\mathrm{OH}$ radicals) using old kinetic data underestimates mercury oxidation by at least $50 \%$. Inclusion of iodine in a two-step mercury oxidation 
mechanism, where an $\mathrm{BrHgI}$ aggregate is formed, helps to reconcile the modelled RGM with the observations. However, a recent revision of the $\mathrm{HgBr}$ thermal dissociation rate together with high level ab initio calculations of $\mathrm{X}-\mathrm{HgBr}$ binding energies $\left(\mathrm{X}=\mathrm{NO}_{2}, \mathrm{HO}_{2}, \mathrm{Br}, \mathrm{BrO}\right.$, I, IO) and our MESMER-calculated rate constants indicate that only $\mathrm{NO}_{2}$ and $\mathrm{HO}_{2}$ concentrations would be high enough to generate the observed RGM levels in competition with $\mathrm{HgBr}$ dissociation. This suggests that $\mathrm{HO}_{2}$ and/or $\mathrm{NO}_{2}$ aggregation with $\mathrm{HgBr}$ could be another possibility to explain the enhanced RGM production over the tropical MBL. Furthermore, the cause of unusually high night-time RGM levels observed from 23-25 October remains unclear.

Given that $\mathrm{Hg}(\mathrm{II})$ is readily deposited back to the ocean (Holmes et al., 2009), the observation of enhanced atmospheric mercury oxidation implies enhanced mercury deposition. Our results indicate that the oxidation mechanisms included in mercury transport and chemistry models are missing a major process and therefore do not provide an adequate description of atmosphere-ocean exchanges of mercury in the tropical oceans. To solve this problem, new laboratory and field studies on the kinetics and mechanism of mercury oxidation are needed.

\section{Supplementary material related to this article is available online at http://www.atmos-chem-phys.net/14/ 1323/2014/acp-14-1323-2014-supplement.pdf.}

Acknowledgements. The authors are grateful to John M. C. Plane (University of Leeds) and Daniel Jacob (Harvard University) for helpful discussions. Funding of this project was provided by the the Spanish National Research Council (CSIC), and the Regional Government of Castilla-La Mancha (FGMACLM) in Spain, the Clayton H. Riddell Endowment Fund and the University of Manitoba's Research Grant Program (URGP) in Canada. We thank Carlos Ordóñez, Mario Agama, Francisco Paredes, Emy Komatsu, and Carl Bartels for field assistance, and the Instituto Nacional de Meteorología e Hidrología (INAMHI, Ecuador) and the Galápagos National Park (Research project PC-03-10) for logistic support. We thank Theodore Dibble, an anonymous referee and Editor Alex Pszenny for their insightful and constructive comments on an earlier version of the manuscript.

Edited by: A. Pszenny

\section{References}

Ambrose, J. L., Lyman, S. N., Huang, J., Gustin, M. S., and Jaffe, D. A.: Fast time resolution oxidized mercury measurements during the Reno Atmospheric Mercury Intercomparison Experiment (RAMIX), Environ. Sci. Technol., 47, 7285-7294, 2013.

Ariya, P. A., Khalizov, A., and Gidas, A.: Reactions of gaseous mercury with atomic and molecular halogens: Kinetics, product stud- ies, and atmospheric implications, J. Phys. Chem. A, 106, 73107320, doi:10.1021/jp020719o, 2002.

Balabanov, N. B., Shepler, B. C., and Peterson, K. A.: Accurate Global Potential Energy Surface and Reaction Dynamics for the Ground State of $\mathrm{HgBr}_{2}$, J. Phys. Chem. A 109, 8765-8773, 2005.

Calvert, J. G. and Lindberg, S. E.: The potential influence of iodinecontaining compounds on the chemistry of the troposphere in the polar spring. II. Mercury depletion, Atmos. Environ., 38, 51055116, 2004.

Davies, J. W., Green, N. J. B., and Pilling, M. J.: The testing of models for unimolecular decomposition via inverse Laplace transformation of experimental recombination rate data, Chem. Phys. Lett., 126, 373-379, 1986.

Dibble, T. S., Zelie, M. J., and Mao, H.: Thermodynamics of reactions of $\mathrm{ClHg}$ and $\mathrm{BrHg}$ radicals with atmospherically abundant free radicals, Atmos. Chem. Phys., 12, 10271-10279, doi:10.5194/acp-12-10271-2012, 2012.

Donohoue, D. L., Bauer, D., and Hynes, A. J.: Temperature and pressure dependent rate coefficients for the reaction of $\mathrm{Hg}$ with $\mathrm{Cl}$ and the reaction of $\mathrm{Cl}$ with $\mathrm{Cl}$ : A pulsed laser photolysispulsed laser induced fluorescence study, J. Phys. Chem. A, 109, 7732-7741, 2005.

Faloona, I., Lenschow, D. H., Campos, T., Stevens, B., van Zanten, M., Blomquist, B., Thornton, D., Bandy, A., and Gerber, H.: Observations of entrainment in eastern Pacific marine stratocumulus using three conserved scalars, J. Atmos. Sci., 62, 3268-3285, doi:10.1175/jas3541.1, 2005.

Fayt, C., De Smedt, I., Letocart, V., Merlaud, A., Pinardi, G., and Van Roozendael, M.: QDOAS 1.00. Software User Manual, Belgian Institute for Space Aeronomy, Belgium, 2011.

Feddersen, D. M., Talbot, R., Mao, H., and Sive, B. C.: Size distribution of particulate mercury in marine and coastal atmospheres, Atmos. Chem. Phys., 12, 10899-10909, doi:10.5194/acp-1210899-2012, 2012.

Fitzgerald, W. F., Gill, G. A., and Kim, J. P.: An equatorial Pacific Ocean source of atmospheric mercury, Science, 224, 597-599, 1984.

Glowacki, D. R., Liang, C.-H., Morley, C., Pilling, M. J., and Robertson, S. H.: MESMER: An open-source master equation solver for Multi-Energy Well Reactions, J. Phys. Chem. A, 116, 9545-9560, 2012.

Gómez Martín, J. C., Mahajan, A. S., Hay, T. D., Prados-Román, C., Ordóñez, C., MacDonald, S. M., Plane, J. M. C., Sorribas, M., Gil, M., Paredes Mora, J. F., Agama Reyes, M. V., Oram, D. E., Leedham, E., and Saiz-Lopez, A.: Iodine chemistry in the eastern Pacific marine boundary layer, J. Geophys. Res., 118, 887-904, 2013.

Goodsite, M. E., Plane, J. M. C., and Skov, H.: A theoretical study of the oxidation of $\mathrm{Hg}^{0}$ to $\mathrm{HgBr}_{2}$ in the troposphere, Environ. Sci. Technol., 38, 1772-1776, 2004.

Goodsite, M. E., Plane, J. M. C., and Skov, H.: Correction to a theoretical study of the oxidation of $\mathrm{Hg}^{0}$ to $\mathrm{HgBr}_{2}$ in the troposphere, Environ. Sci. Technol., 46, 5262-5262, 2012.

Gustin, M. S., Huang, J., Miller, M. B., Peterson, C., Jaffe, D. A., Ambrose, J., Finley, B. D., Lyman, S. N., Call, K., Talbot, R., Feddersen, D., Mao, H., and Lindberg, S. E.: Do we understand what the mercury speciation instruments are actually measuring? Results of RAMIX, Environ. Sci. Technol., 47, 7295-7306, 2013. 
Hall, B.: The gas phase oxidation of elemental mercury by ozone, Water Air Soil Pollut., 80, 301-315, 1995.

Hedgecock, I. M. and Pirrone, N.: Mercury and photochemistry in the marine boundary layer-modelling studies suggest the in situ production of reactive gas phase mercury, Atmos. Environ., 35, 3055-3062, 2001.

Holmes, C. D., Jacob, D. J., Mason, R. P., and Jaffe, D. A.: Sources and deposition of reactive gaseous mercury in the marine atmosphere, Atmos. Environ., 43, 2278-2285, 2009.

Holmes, C. D., Jacob, D. J., Corbitt, E. S., Mao, J., Yang, X., Talbot, R., and Slemr, F.: Global atmospheric model for mercury including oxidation by bromine atoms, Atmos. Chem. Phys., 10, 12037-12057, doi:10.5194/acp-10-12037-2010, 2010.

Hönninger, G., von Friedeburg, C., and Platt, U.: Multi axis differential optical absorption spectroscopy (MAX-DOAS), Atmos. Chem. Phys., 4, 231-254, doi:10.5194/acp-4-231-2004, 2004.

Huang, J., Miller, M. B., Weiss-Penzias, P., and Gustin, M. S.: Comparison of reactive mercury measurements made with $\mathrm{KCl}$ coated denuders, nylon membranes, and cation exchange membranes, Environ. Sci. Technol., 47, 7307-7316, 2013.

Kim, J. P. and Fitzgerald, W. F.: Sea-air partitioning of mercury in the equatorial Pacific Ocean, Science, 231, 1131-1133, 1986.

Landis, M. S., Stevens, R. K., Schaedlich, F., and Prestbo, E. M.: Development and characterization of an annular denuder methodology for the measurement of divalent inorganic reactive gaseous mercury in ambient air, Environ. Sci. Technol., 36, 3000-3009, 2002.

Laurier, F. and Mason, R.: Mercury concentration and speciation in the coastal and open ocean boundary layer, J. Geophys. Res., 112, D06302, doi:10.1029/2006JD007320, 2007.

Laurier, F. J. G., Mason, R. P., Whalin, L., and Kato, S.: Reactive gaseous mercury formation in the North Pacific Ocean's marine boundary layer: A potential role of halogen chemistry, J. Geophys. Res. Atmos., 108, 4529, doi:10.1029/2003JD003625, 2003.

Lin, C. J. and Pehkonen, S. O.: The chemistry of atmospheric mercury: a review, Atmos. Environ., 33, 2067-2079, 1999.

Lindberg, S., Bullock, R., Ebinghaus, R., Engstrom, D., Feng, X., Fitzgerald, W., Pirrone, N., Prestbo, E., and Seigneur, C.: A synthesis of progress and uncertainties in attributing the sources of mercury in deposition, Ambio, 36, 19-32, 2007.

Linqvist, O. and Rodhe, H.: Atmospheric mercury - a review, Tellus, 37B, 136-159, 1985.

Mahajan, A. S., Plane, J. M. C., Oetjen, H., Mendes, L., Saunders, R. W., Saiz-Lopez, A., Jones, C. E., Carpenter, L. J., and McFiggans, G. B.: Measurement and modelling of tropospheric reactive halogen species over the tropical Atlantic Ocean, Atmos. Chem. Phys., 10, 4611-4624, doi:10.5194/acp-10-4611-2010, 2010.

Müller, D., Wip, D., Warneke, T., Holmes, C. D., Dastoor, A., and Notholt, J.: Sources of atmospheric mercury in the tropics: continuous observations at a coastal site in Suriname, Atmos. Chem. Phys., 12, 7391-7397, doi:10.5194/acp-12-7391-2012, 2012.

Obrist, D., Tas, E., Peleg, M., Matveev, V., Fain, X., Asaf, D., and Luria, M.: Bromine-induced oxidation of mercury in the midlatitude atmosphere, Nature Geosci., 4, 22-26, 2011.

Pal, B. and Ariya, P. A.: Gas-phase HO-Initiated reactions of elemental mercury: Kinetics, product studies, and atmospheric implications, Environ. Sci. Technol., 38, 5555-5566, 2004.
Plane, J. M. C. and Saiz-Lopez, A.: UV-visible differential optical absorption spectroscopy (DOAS), in: Analytical Techniques for Atmospheric Measurement, edited by: Heard, D. E., Blackwell Publishing, Oxford, 2006.

Platt, U., Allan, W., and Lowe, D.: Hemispheric average $\mathrm{Cl}$ atom concentration from ${ }^{13} \mathrm{C} /{ }^{12} \mathrm{C}$ ratios in atmospheric methane, Atmos. Chem. Phys., 4, 2393-2399, doi:10.5194/acp-4-2393-2004, 2004.

Raofie, F. and Ariya, P. A.: Kinetics and products study of the reaction of BrO radicals with gaseous mercury, J. Physique IV, 107, 1119-1121, 2003.

Robertson, S. H., Pilling, M. J., Baulch, D. L., and Green, N. J. B.: Fitting of pressure-dependent kinetic rate data by master equation inverse Laplace transform analysis J. Phys. Chem., 99, 13452-13460, 1995.

Saiz-Lopez, A. and von Glasow, R.: Reactive halogen chemistry in the troposphere, Chem. Soc. Rev., 41, 6448-6472, doi:10.1039/c2cs35208g, 2012.

Saiz-Lopez, A., Plane, J. M. C., Mahajan, A. S., Anderson, P. S., Bauguitte, S. J.-B., Jones, A. E., Roscoe, H. K., Salmon, R. A., Bloss, W. J., Lee, J. D., and Heard, D. E.: On the vertical distribution of boundary layer halogens over coastal Antarctica: implications for $\mathrm{O}_{3}, \mathrm{HO}_{\mathrm{x}}, \mathrm{NO}_{\mathrm{x}}$ and the $\mathrm{Hg}$ lifetime, Atmos. Chem. Phys., 8, 887-900, doi:10.5194/acp-8-887-2008, 2008.

Saiz-Lopez, A., Lamarque, J.-F., Kinnison, D. E., Tilmes, S., Ordóñez, C., Orlando, J. J., Conley, A. J., Plane, J. M. C., Mahajan, A. S., Sousa Santos, G., Atlas, E. L., Blake, D. R., Sander, S. P., Schauffler, S., Thompson, A. M., and Brasseur, G.: Estimating the climate significance of halogen-driven ozone loss in the tropical marine troposphere, Atmos. Chem. Phys., 12, 3939-3949, doi:10.5194/acp-12-3939-2012, 2012.

Sandu, A. and Sander, R.: Technical note: Simulating chemical systems in Fortran90 and Matlab with the Kinetic PreProcessor KPP-2.1, Atmos. Chem. Phys., 6, 187-195, doi:10.5194/acp-6187-2006, 2006.

Schaeffer, B. A., Morrison, J. M., Kamykowski, D., Feldman, G. C., Xie, L., Liu, Y., Sweet, W., McCulloch, A., and Banks, S.: Phytoplankton biomass distribution and identification of productive habitats within the Galapagos Marine Reserve by MODIS, a surface acquisition system, and in-situ measurements, Remote Sens. Environ., 112, 3044-3054, 2008.

Selin, N. E.: Global Biogeochemical Cycling of Mercury: A Review, Ann. Rev. Environ. Resour., 34, 43-63, 2009.

Simpson, W. R., von Glasow, R., Riedel, K., Anderson, P., Ariya, P., Bottenheim, J., Burrows, J., Carpenter, L. J., Frieß, U., Goodsite, M. E., Heard, D., Hutterli, M., Jacobi, H.-W., Kaleschke, L., Neff, B., Plane, J., Platt, U., Richter, A., Roscoe, H., Sander, R., Shepson, P., Sodeau, J., Steffen, A., Wagner, T., and Wolff, E.: Halogens and their role in polar boundary-layer ozone depletion, Atmos. Chem. Phys., 7, 4375-4418, doi:10.5194/acp-74375-2007, 2007.

Soerensen, A. L., Skov, H., Jacob, D. J., Soerensen, B. T., and Johnson, M. S.: Global concentrations of gaseous elemental mercury and reactive gaseous mercury in the marine boundary layer, Environ. Sci. Technol., 44, 7425-7430, 2010a.

Soerensen, A. L., Sunderland, E. M., Holmes, C. D., Jacob, D. J., Yantosca, R. M., Skov, H., Christensen, J. H., Strode, S. A., and Mason, R. P.: An improved global model for air-sea exchange of 
mercury: High concentrations over the North Atlantic, Environ. Sci. Technol., 44, 8574-8580, 2010 b.

Soerensen, A. L., Mason, R. P., Balcom, P. H., and Sunderland, E. M. Drivers of surface ocean mercury concentrations and air-sea exchange in the west Atlantic Ocean, Environ. Sci. Technol., 47, 7757-7765, 2013.

Steffen, A., Douglas, T., Amyot, M., Ariya, P., Aspmo, K., Berg, T., Bottenheim, J., Brooks, S., Cobbett, F., Dastoor, A., Dommergue, A., Ebinghaus, R., Ferrari, C., Gardfeldt, K., Goodsite, M. E., Lean, D., Poulain, A. J., Scherz, C., Skov, H., Sommar, J., and Temme, C.: A synthesis of atmospheric mercury depletion event chemistry in the atmosphere and snow, Atmos. Chem. Phys., 8, 1445-1482, doi:10.5194/acp-8-1445-2008, 2008.

Steffen, A., Scherz, T., Olson, M., Gay, D., and Blanchard, P.: A comparison of data quality control protocols for atmospheric mercury speciation measurements, J. Environ. Monit., 14, 752765,2012

Strode, S. A., Jaegle, L., Selin, N. E., Jacob, D. J., Park, R. J., Yantosca, R. M., Mason, R. P., and Slemr, F.: Air-sea exchange in the global mercury cycle, Global Biogeochem. Cy., 21, GB1017, doi:10.1029/2006GB002766, 2007.
Subir, M., Ariya, P. A., and Dastoor, A. P.: A review of uncertainties in atmospheric modeling of mercury chemistry. I. Uncertainties in existing kinetic parameters e Fundamental limitations and the importance of heterogeneous chemistry, Atmos. Environ., 45, 5664-5676, 2011.

Tekran: Tekan 2537 Mercury Monitor Detection Limit. Summary of Known Estimates, Tekran Instruments Corp., Toronto, ON, Canada, 2011.

Theys, N., Van Roozendael, M., Hendrick, F., Yang, X., De Smedt, I., Richter, A., Begoin, M., Errera, Q., Johnston, P. V., Kreher, K., and De Mazière, M.: Global observations of tropospheric BrO columns using GOME-2 satellite data, Atmos. Chem. Phys., 11, 1791-1811, doi:10.5194/acp-11-1791-2011, 2011.

Thompson, A. M.: The effect of clouds on photolysis rates and ozone formation in the unpolluted troposphere, J. Geophys. Res., 89, 1341-1349, 1984.

von Glasow, R., von Kuhlmann, R., Lawrence, M. G., Platt, U., and Crutzen, P. J.: Impact of reactive bromine chemistry in the troposphere, Atmos. Chem. Phys., 4, 2481-2497, doi:10.5194/acp-42481-2004, 2004. 